\title{
PENGEMBANGAN E-MODUL BERBASIS PTOJECT BASED LEARNING PADA MATA PELAJARAN PEMROGRAMAN BERORIENTASI OBJEK KELAS XI RPL DI SMK NEGERI 2 TABANAN
}

\author{
I Wayan Bayu Permana ${ }^{1}$, I Made Agus Wirawan ${ }^{2}$, I Gede Partha Sindu ${ }^{3}$ \\ 1,2,3 Fakultas Teknik dan Kejuruan, Universitas Pendidikan Ganesha \\ Singaraja, Indonesia
}

email: permanabayu2@gmail.com, imade.aguswirawan@undiksha.ac.id, partha.sindu@undiksha.ac.id

\begin{abstract}
Abstrak
Penelitian ini bertujuan untuk (1) Untuk menghasilkan rancangan dan mengimplementasikan hasil rancangan E-Modul Berbasis Project Based Learning Pada Mata Pelajaran Pemrograman Berorientasi Objek Kelas XI RPL di SMK Negeri 2 Tabanan, (2) Untuk mengetahui respon guru dan siswa terhadap Pengembangan E-Modul Berbasis Project Based Learning Pada Mata Pelajaran Pemrograman Berorientasi Objek Kelas XI RPL di SMK Negeri 2 Tabanan. pengembangan modul elektronik ini menerapakan model pembelajaran project based learning.

Jenis penelitian yang digunakan adalah penelitian dan pengembangan (R\&D) dengan model ADDIE dimana model ini memiliki lima tahapan yaitu Analyze, Design, Development, Implementation, dan Evaluation. Subjek penelitian ini yaitu siswa kelas XI jurusan RPL di SMK Negeri 2 Tabanan tahun ajaran 2016/2017. Untuk mengetahui respon guru dan siswa terhadap e-modul Pemrograman Berorientasi Objek diperoleh dengan menggunakan metode angket.

Hasil penelitian yang diperoleh terlihat bahwa (1) Hasil rancangan dan implementasi pengembangan e-modul berbasis project based learning pada mata pelajaran Pemrograman Berorientasi Objek kelas XI RPL SMK N 2 Tabanan sudah dinyatakan berhasil dikembangkan berdasarkan hasil pengujian yang telah dilakukan (2) Hasil analisis data respon guru menunjukkan bahwa, didapatkan hasil respon dengan kategori positif pada nilai rata-rata respon guru yang dikonversikan ke dalam tabel penggolongan respon. Sedangkan untuk respon siswa terhadap pengembangan e-modul didapatkan hasil respon dengan kategori positif pada nilai rata-rata respon siswa yang dikonversikan ke dalam tabel penggolongan respon siswa.
\end{abstract}

Kata kunci: E-Modul, Pemrograman Berorientasi Objek, Project Based Learning

\begin{abstract}
This research had purpose: (1) to design and implement e-module development based on project based learning object oriented programming subject class XI RPL in SMK Negeri 2 Tabanan, (2) to know teacher and student responds toward development of emodule development based on project based learning object oriented programming subject class XI RPL in SMK Negeri 2 Tabanan. Development for this electronic module is apply project based learning model.

Type of research used is research and development (R\&D) with the ADDIE model where this is has five stages: Analyze, Design, Development, Implementation, and Evaluation. The subjects of this research were students grade XI of RPL in SMK Negeri 2 Tabanan year 2016/2017. Questionnaire with agree and disagree responds was used as a tools to attain teacher and student responds toward e-module object oriented programming.
\end{abstract}


The result of the research shows that (1) The result of design and implementation of project based on project based learning object oriented programming subject class XI RPL in SMK Negeri 2 Tabanan has been stated successfully developed based on test result which have been done (2) The results of teacher response analysis showed that, obtained the response with positive category on the average teacher response rate converted into the response classification table. As for the students response to the development of e-module obtained response results with positive category on the average value of student responses are converted into the classification table student response.

\section{Keywords : E-Module, Object Oriented Programming ,Project Based Learning}

\section{PENDAHULUAN}

Pendidikan dalam arti luas dapat diartikan sebagai faktor yang sangat penting yang dapat menunjang kemajuan bangsa, karena melalui pendidikan, Sumber Daya Manusia (SDM) yang unggul dan berkualitas dapat tercipta, yang nantinya akan membangun dan membuat bangsa tersebut menjadi bangsa yang maju. Demi terciptanya Sumber Daya Manusia (SDM) yang unggul, maka dibutuhkan berbagai faktor dan salah satu faktor tersebut adalah faktor guru sebagai seorang tenaga pendidik. Pendidikan yang menjadi pondasi kuat berkembangnya suatu negara adalah pendidikan yang bermutu. (Suderadjad, 2005 : 17) menyatakan bahwa "pendidikan bermutu adalah pendidikan yang mampu menghasilkan lulusan yang memiliki kemampuan atau kompetensi, baik kompetensi akademik maupun kompetensi keuruan, yang dilandasi oelh kompetensi personal dan social, serta nilai - nilai akhlak mulia, yang keseluruhanya merupakan kecakapan hidup, lebih lanjut Sudradjat megemukakan pendidikan bermutu adalah pendidikan yang mampu menghasilkan manusia seutuhnya (manusia paripurna) atau manusia dengan pribadi yang integral (integrated personality) yaitu mereka yang mampu mengintegralkan iman, ilmu, dan amal. Dengan demikian kegiatan belajar mengajar hendaknya sejalan dengan motivasi dan sasaran belajar, sehinga tujuan pembelajaran dapat dikuasai secara optimal sesuai dengan perkembangan teknologi dan informasi.

Sekolah Menengah Kejuruan (SMK) merupakan salah satu bentuk satuan pendidikan formal yang menyelenggarakan pendidikan kejuruan pada jenjang menengah sebagai lanjutan dari SMP, MTs atau bentuk lain yang sederajat yang bertujuan untuk mempersiapkan tenaga yang memiliki keterampilan dan pengetahuan yang sesuai dengan kebutuhan persyaratan lapangan kerja dan mampu mengembangkan potensi dirinya dalam mengadopsi dan beradaptasi dengan perkembangan teknologi. Dalam proses pendidikan kejuruan perlu ditanamkan pada siswa pentingnya penguasaan pengetahuan dan teknologi, keterampilan bekerja, sikap mandiri, efektif dan efisien.

Perkembangan teknologi informasi sangat berpengaruh besar pada proses belajar mengajar. Salah satu penerapan teknologi informasi dalam kegiatan pembelarajan yaitu modul elektronik (emodul). Modul merupakan suatu cara pengorganisasian materi pelajaran yang memperhatikan fungsi pendidikan (Santyasa, 2009 : 9) Artinya melalui modul suatu pembelajaran diharapkan mampu membawa peserta didik pada kompetensi dasar yang diharapkan. Modul elektronik dapat menampilkan teks, gambar, animasi, dan video melalui piranti computer serta dapat mengurangi

penggunaan kertas dalam proses belajar - mengajar. Dengan adanya perubahan tersebut seorang pengembang dalam hal ini mengubah penyajian bahan ajar berupa modul cetak menjadi digital atau modul elektronik (e-modul) . Penyajian bahan ajar dalam bentuk elektronik ini tentunya akan menjadi lebih menarik dan memberikan berbagai kemudahan. Keberadaan media pembelajaran ini pada akhirnya dapat menunjang dan melengkapi peran guru sebagai satu-satunya sumber informasi bagi peserta didik. Selain itu Modul elektronik ini 
diharapkan dapat digunakan sebagai alternatif pembelajaran yang efisien dan efektif, serta interaktif. Sehingga minat dan hasil belajar siswa meningkat.

Pemrograman Berorientasi Objek merupakan pemrograman yang berorientasikan kepada objek, dimana semua data dan fungsi dibungkus dalam class-class atau object-object. Setiap object dapat menerima pesan, memproses data, mengirim, menyimpan dan memanipulasi data. Beberapa objek berinteraksi dengan saling memberikan informasi satu terhadap yang lainnya. Pemrograman Berbasis Objek diperlukan sebuah media yang dapat mendukung aktivitas siswa dalam mempelajari materi Pemrograman Berbasis Objek sehingga siswa dapat belajar mandiri tanpa harus bergantung pada guru mata pelajaran dalam mengembangkan bakat dan potensi yang dimiliki. Namun, hal tersebut tidak terlihat di SMK Negeri 2 Tabanan. Berdasarkan wawancara dengan salah seorang guru diperoleh data bahwa belum adanya sumber belajar ataupun bahan ajar yang dipakai dalam kegiatan belajar mengajar dan proses belajar mengajar masih berpusat pada guru, sehingga kegiatan belajar mengajar siswa terpaku pada penjelasan guru. Hal ini menyebabkan siswa menjadi terbatas untuk melakukan pengembangan diri dengan potensi yang dimiliki sesuai dengan bidang keahliannya.

Berdasarkan hasil observasi dengan guru yang mengajar Pemrograman Berorientasi Objek yaitu Ni Ketut Eniyawati S.Kom di SMK Negeri 2 Tabanan menggunakan metode wawancara transcript dan pemberian angket diperoleh data bahwa guru sulit mencari materi yang sesuai dengan kemampuan siswa sehingga siswa sulit memahami materi yang telah diberikan. Oleh karena itu pencarian materi dilakukan dengan menggabungkan materi yang terdapat di beberapa buku dan internet yang sebelumnya sudah di sesuaikan dengan silabus yang ada. Sedangkan dari angket guru yang diberikan kepada guru Pemrograman Berorientasi Objek menyatakan perlu dan mendukung dikembangkannya e-modul. Observasi kedua dilakukan penyebaran angket pada siswa kelas XI RPL SMK Negeri 2 Tabanan untuk mengetahui karakteristik siswa. Dimana didapatkan hasil 76,2\% Menyatakan senang mencari materi di internet sedangkan 23,8 \% menyataan kurang tertarik mencari materi di internet. Materi yang di peroleh dari internet sebagaian besar memiliki sumber yang kurang jelas dan materi yang didapat juga rancu, sehingga perlu dikembangkanya suatu tempat atau wadah yang bisa memfasilitasi siswa dalam pencarian materi yang sesuai dengan silabus yang ada dan sudah tersusun secara sistematis. Observasi ketiga dilakukan dengan cara melihat secara langsung proses belajar mengajar di kelas XI RPL SMK N 2 Tabanan, diperoleh hasil bahwa pada saat proses belejar mengajar guru masih menggunakan metode ceramah dan penyampaian materi yang menggunakan power point sehingga membuat siswa kurang tertarik dalam mengikuti proses pembelajaran tersebut. Fasilitas penunjang lainnya seperti Lab komputer pada SMK Negeri 2 Tabanan sudah sangat memadai dimana sudah tersedia 40 PC untuk lab tersebut, serta kebanyakan siswa juga sudah mempunyai Laptop.

Berbagai pengembangan e-modul telah banyak dilakukan salah satunya yang telah dikembangkan oleh Sitti Ghaliyah, Fauzi Bakri, Siswoyo (2015) yaitu Pengembangan modul elektronik berbasis model Learning Cycle 7E pada pokok bahasan Fluida dinamik untuk siswa SMA kelas XI. Adapun hasil penelitian dari sejumlah persentase respon siswa terhadap pengembangan emodul dapat dikategorikan sangat positif, seperti halanya Penelitian yang dilakukan Wijayanto, Muhammad Saifuddin Zuhri (2014) yaitu Pengembangan E-Modul Berbasis Flip Book Maker dengan model Project Based Learning untuk mengembangkan kemampuan pemecahan masalah matematika adapun hasilnya Berdasarkan hasil penelitian penggunaan $E$ Modul ini didapatkan penilain positif dikarenakan materi pembelajaran menjadi sangat mudah dipahami oleh siswa, selain itu, pengoprasian modul tersebut sangat 
mudah, unsur music dan animasi dinilai dapat meningkatkan motivasi, minat dan aktivitas belajar para peserta didik, serta penelitian Rinta Doski Yance, Ermaniati Ramli, dan Fatni Mufit (2013) yaitu Pengaruh Penerapan Model Project Based Learning (Pbl) Terhadap Hasil Belajar Fisika Siswa Kelas XI IPA SMA Negeri 1 Batipuh Kabupaten Tanah Datar Berdasarkan hasil penelitian diperoleh perbedaan hasil belajar siswa antara kelas eksperimen dengan kelas kontrol pada ranah afektif, kognitif, dan psikomotor secara signifikan. Perbedaan ini diyakini disebabkan oleh pengaruh penerapan PBL terhadap hasil belajar siswa. Dengan demikian, dapat disimpulkan bahwa PBL mempunyai pengaruh yang berarti terhadap hasil belajar fisika siswa pada ranah kognitif, afektif, dan psikomotor.

Berdasarkan uraian di atas, maka perlu dilakukan pengembangan media pembelajaran untuk mata pelajaran produktif mata plajaran Pemrograman Berbasis Objek sehingga siswa dapat belajar secara mandiri dan dapat mengurangi peran guru dalam kegiatan pembelajaran. Tujuan utama dari penelitian ini adalah untuk mengetahui hasil dari penerapan E-Modul Pada Mata Pelajaran Pemrograman Berbasis Objek Kelas XI di SMK Negeri 2 Tabanan. Berdasarkan permasalahan tersebut.

\section{KAJIAN TEORI}

\section{A. Perangkat Pembelajaran}

Menurut Prasetyo (2011:16), perangkat pembelajaran adalah alat atau perlengkapan untuk melaksanakan proses yang memungkinkan pendidik dan peserta didik melakukan kegiatan pembelajaran. Perangkat pembelajaran menjadi pegangan bagi guru dalam melaksanakan pembelajaran baik di kelas, laboratorium atau di luar kelas. Menurut Ibrahim (dalam Trianto, 2008), perangkat pembelajaran yang diperlukan dalam mengelola proses belajar mengajar dapat berupa: silabus, Rencana Pelaksanaan Pembelajaran (RPP), Lembar Kerja Siswa (LKS), Instrumen Evaluasi atau Tes Hasil Belajar
(THB), media pembelajaran, serta buku ajar siswa

\section{B. Teori Belajar}

Belajar adalah sebuah proses perubahan di dalam kepribadian manusia dan perubahan tersebut ditampakkan dalam bentuk peningkatan kualitas dan kuantitas tingkah laku seperti peningkatan kecakapan, pengetahuan, sikap, kebiasaan, pemahaman, ketrampilan, daya pikir, dan kemampuan-kemampuan yang lain. Pengertian belajar menurut kamus bahasa Indonesia, Belajar adalah berusaha memperoleh kepandaian atau ilmu, berlatih, berubah tingkah laku atau tanggapan yang disebabkan oleh pengalaman. Menurut (Baharuddin, 2010) belajar merupakan kegiatan yang sering dilakukan setiap orang. Belajar dilakukan hampir setiap waktu, kapan saja, dimana saja, dan sedang melakukan apa saja. Belajar juga merupakan aktivitas yang dilakukan seseorang untuk mendapatkan perubahahan dalam dirinya melalui pelatihan-pelatihan atau pengalamanpengalaman. Belajar dapat membawa perubahan pada si pelaku, baik perubahan pengetahuan, sikap, maupun ketrampilan. Pengertian belajar sendiri adalah suatu perubahan dalam tingkah laku dan penampilan sebagai hasil dari praktik dan pengalaman. Dalam proses pembelajaran diperlukan model yang tepat sesuai dengan karakteristik siswa dan mata pelajaran. Seperti contohnya penggunaan model pembelajaran project based learning pada mata pelajaran pemrograman berorientasi objek, dimana pada model pembelajaran ini siswa di tuntut untuk bisa menggali pengetahuanya sendiri dan memecah masalah yang dirangkum oleh guru dalam kerja proyek, guru di sini bersifat sebagai pendamping dan pembimbing. Model pembelajaran ini sangat sesuai dengan teori belajar kontruktivisme dimana guru tidak hanya memberikan pengetahuan kepada siswa, namun siswa juga harus berperan aktif membangun sendiri pengetahuan di dalam memorinya. Terdapat beberapa macam teori belajar yang dapat diterapkan 
namun dalam pengembangan e-modul ini menerapkan teori belajar kontruktivisme.

\section{Modul Ajar}

Modul merupakan suatu cara pengorganisasian materi pelajaran yang memperhatikan fungsi pendidikan. Artinya, melalui modul suatu pembelajaran diharapkan mampu membawa peserta didik pada kompetensi dasar yang diharapkan. Lebih lanjut, (Santyasa, 2009 : 9) menyatakan bahwa strategi pengorganisasian materi pembelajaran pada modul mengandung squencing yang mengacu pada pembuatan urutan penyajian materi pelajaran, dan synthe sizing yang mengacu pada upaya untuk menunjukkan kepada peserta didik keterkaitan antara fakta, konsep, prosedur dan prinsip yang terkandung dalam materi pembelajaran. Untuk merancang materi pem belajaran, terdapat lima kategori kapabilitas yang dapat dipelajari oleh peserta didik, yaitu (1) informasi verbal, (2) keterampilan intelektual, (3) strategi kognitif, (4) sikap, dan (5) keterampilan motorik. Strategi pengorgani sasi an materi pembelajaran terdiri dari tiga tahapan proses berpikir, yaitu (1) pembentukan konsep, (2) intepretasi konsep, dan (3) aplikasi prinsip. Strategistrategi tersebut memegang peranan sangat penting dalam mendesain pembelajaran. Kegunaannya dapat membuat mahasiswa lebih tertarik dalam belajar, mahasiswa otomatis belajar bertolak dari prerequisites, dan dapat meningkatkan hasil belajar (Santyasa, 2009 : 9)

\section{E-Modul}

Modul elektornik atau E-Modul merupakan tampilan informasi dalam format buku yang disajikan secara elektronik dengan menggunakan harddisk, disket, CD, atau flashdisk dan dapat di baca dengan menggunakan komputer atau alat pembaca elektronik (Wijayanto, 2014 : 20-37) E-Modul merupakan alat atau sarana pembelajaran yang berisi materi, metode, batasanbatasan, dan cara mengevaluasi yang dirancang secara sistematis dan menarik untuk mencapai kompetensi yang diharapkan sesuai dengan tingkat kompleksitasnya secara elektroknik.
Sedangkan (Mulyasa, 2005 : 231) menyatakan modul sebagai paket belajar mandiri yang dirancang secara sistematis untuk membantu peserta didik mencapai tujuan belajar

\section{E. Model Pembelajaran Project Based Learning \\ Project Based Learning / pembelajaran} berbasis proyek merupakan model pembelajaran yang memberikan kesempatan kepada guru untuk mengelola pembelajaran dikelas dengan melibatkan kerja proyek (Wena, 2009 : 144) .Fokus pembelajaran terletak pada konsep-konsep dan prisnsip-prinsip inti dari suatu disiplin studi, melibatkan pembelajaran dalam investigasi pemecahan masalah dan kegiatan tugas-tugas bermakna, memberi kesempatan kepada pembelajar agar bekerja secara otonommengkonstruk pengetahuan mereka sendiri, dan mencapai puncaknya menghasilkan produk nyata (Santyasa, 2011). Proyek yang dibuat pebelajar selama proyek memberikan hasil secara ontentik dapat diukur oleh fasilitator didalam pembelajaran. Oleh karena itu fasilitator tidak lebih aktif dan melatih seara langsung, akan tetapi lebih aktif menjadi pendamping, pembimbing mediator, dan memahai pikiran pembelajar (Santyasa, $2011: 11-12$ )

\section{F. Mata Pelajaran Pemrograman \\ Berorientasi Objek \\ Pemrograman Berorientasi Objek} merupakan salah satu mata pelajaran wajib paket keahlian RPL yang harus dicapai oleh siswa SMK. Tujuan dalam mempelajari Materi Pemrograman Berorientasi Objek agar siswa dapat memiliki keterampilan, sikap dan kompetensi yang berkaitan dengan konsep Pemrograman Berorientasi Objek, Dasar - dasar dan Aturan - Aturan Pemrograman Berorientasi Objek, Konsep Class dan Objek, Enkapsulasi, Inheritas, Polimorphisme, dan Package.

\section{G. Moodle}

Moodle adalah salah satu LMS, yang di perkenalkan pertama kali oleh Martin. Kata moodle awalnya merupakan kependekan 
dari Modulator Object-Oriented Dynamic Learning Environment, walaupun pada awalnya huruf $M$ kependekan dari kata "Martin's" yang berasal dari Martin Dougiamas sang pembuat moodle. Maksud dari modular disini adalah para developer di seluruh dunia dapat mengembangkan serta menciptakan module-module baru untuk menambah fungsional moodle. MOODLE adalah singakatan dari Modulator ObjectOriented Dynamic Learning Environment yang intinya pengajar dan peserta didik melakukan aktivitas pengajaran dan pelatihan online (Suartama, 2014: 39-57). Secara umum Moodle merupakan salah satu aplikasi dari konsep dan mekanisme belajar mengajar yang memanfaatkan teknologi informasi yang dikenal dengan konsep pembelajaran elektronik atauelearning. Moodle dapat digunakan secara bebas sebagai produk sumber terbuka (open source) di bawah lisensiGNU. Moodle adalah sebuah nama untuk sebuah program aplikasi yang dapat merubah sebuah media pembelajaran kedalam bentuk web. Aplikasi ini memungkinkan siswa untuk masuk kedalam "ruang kelas digital" untuk mengakses materi-materi pembelajaran. Dengan menggunakan Moodle, kita dapat membuat materi pembelajaran, kuis, dan jurnal elektronik

\section{H. Media CAI}

Pada saat ini para pendidik sudah mulai mendapatkan akses untuk menggunakan berbgai macam teknologi guna meningkatkan efektifitas proses belajar dan mengajar. Komputer sebagai salah satu produk teknologi dinilai tepat digunakan sebagai alat bantu pengajaran berbagai macam pendekatan yang dikemas dalam bentuk program pengajaran berbantuan computer atau CAl (Computer Assisted Intruction) seperti : drill and practice, simulasi, tutorial dan permaianan bisa diperoleh lewat computer. Pembelajaran dengan menggunakan dikenal dengan konsep pembelajaran dengan bantuan computer (Computer Assisted Intruction) Konsep CAl berfungsi sebagai penyaji materi pembelajaran, penyimpanan materi pembelajaran, hingga memberikan analisis evaluasi pembelajaran (Musfiqon, 2012: 190). CAI ini di harapkan dapat memebatu proses pembelajaran untuk mendapatkan hasil belajar yang memuaskan. Bahan ajar berbasi (Computer Assisted Intruction) CAI adalah salah satu system penyampaian materi pelajaran yang berbantuan computer yang menggabungkan beberapa media pembelajaran yang interaktif dan menarik kemudian dirancang dan deprogram kedalam system tersebut. Menurut (Kusuma, 2005: 23) CAl dibagi terdiri dari lima langkah, yaitu Tutorial, Latih dan Praktik, Simulasi, Permanian dan Pemecahan Masalah.

I. Kerangka Berpikir

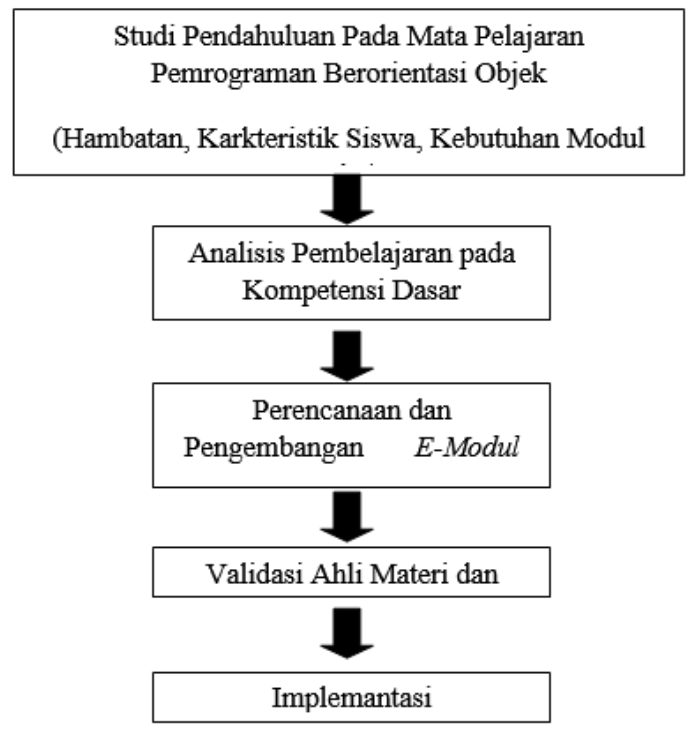

Gambar 1. Kerangka Berpikir

Pada kerangka berpikir pengembangan e-modul hal yang pertama dilakukan adalah melakukan studi pendahuluan pada mata pelajaran Pemrograman Beroreintasi Objek dimana dalam studi pendahuluan dilakukan analisi hambatan yang ada, karakteristik siswa dalam proses pembelajaran, serta kebutuhan modul ajar yang digunakan dalam pemblajaran. Setelah itu dilakukan analisis pembelajaran pada kompetensi dasar yang ada pada silabus. Selanjutnya setalah menganalisis hambatan, karakteristik siswa, kebutuhan modul ajar serta analisis pembelajaran dilakukan perencanaan dan pengembangan e-modul 
yang sesuai dengan analisis yang di dapat, selanjutnya di lakukan validasi ahli materi dan media yang berfungsi untuk mengetahui kekurangan yang ada dalam pembuatan emodul sehingga dapat di evaluasi dan di sempurnakan. Pada tahap terakhir di lakukan implementasi atau penerapan emodul.

\section{METODE}

Jenis penelitian yang digunakan merupakan penelitian pengembangan atau biasa disebut Research and Development ( $R$ \& D) metode penelitian dan pengembangan adalah metode penelitian yang digunakan untuk menghasilkan produk tertentu dan menguji keektifan produk tersebut (Sugiyono, 2009:407). Produkproduk pendidikan yang dihasilkan dapat berupa kurikulum yang spesifik untuk keperluan pendidikan tertentu, metode mengajar, media pendidikan, buku ajar, modul, kompetensi tenaga kependidikan, system evaluasi, model uji kompetensi, penataan ruang kelas untuk model pembelajran tertentu, model unit produksi, model manajemen, system pembinaan pegawai, system penggajian dan lain-lain (Sugiyono, 2009:407). Penelitian ini dilakukan untuk menghasilkan sebuah produk yang akan digunakan dalam dunia pendidikan melalui proses yang alamiah yang diakhiri dengan tahapan validasi. Produk yang dimaksud berupa modul elektronik berbasis model pembelajaraan Project Based Learning pada mata pelajaran pemrograman berorientasi objek kelas XI rekayasa perangkat lunak. Terdapat beberapa model yang bisa digunakan dalam penelitian pengembangan ini, salah satunya yang di gunakan dalam penelitian pengembangan ini adalah ADDIE. Dimana model pengembangan ini terdiri dari lima tahapan, yaitu Alaysis, Design, Development, Implementasion, dan Evaluation.

Menurut (McGriff, 2000:1) bahwa model ADDIE adalah proses desain intruksional berulang, dimana hasil dari evaluasi formatif setaip tahap-tahapnya dapat menyebabkan kembali ke setiap tahap sebelumnya..
Dalam penelitian ini digunakan instrumen berupa angket untuk mengumpulkan data yang dibutuhkan terkait informasi tentang sumber belajar, karakteristik siswa, uji kevalidan e-modul, serta uji respon guru dan siswa terhadap e-modul yang dikembangkan. Teknik pengumpulan data dapat dilihat pada Tabel 1 .

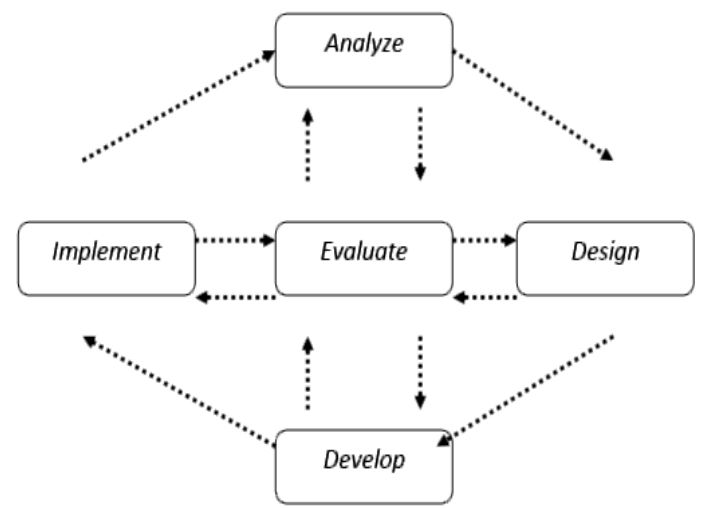

Gambar 3.1 Model ADDIE (Anglada, 2007)

Tabel 1. Teknik Pengumpulan data

\begin{tabular}{|c|c|c|c|}
\hline No. & $\begin{array}{l}\text { Jenis } \\
\text { Data }\end{array}$ & Metode & Sumber Data \\
\hline 1 & $\begin{array}{l}\text { Informasi } \\
\text { tentang } \\
\text { sumber } \\
\text { belajar }\end{array}$ & Angket & $\begin{array}{l}\text { Guru Mata } \\
\text { Pelajaran } \\
\text { Pemrograman } \\
\text { Berorientasi } \\
\text { Objek }\end{array}$ \\
\hline 2 & $\begin{array}{l}\text { Karakteri } \\
\text { stik } \\
\text { pembelaj } \\
\text { ar }\end{array}$ & Angket & $\begin{array}{l}\text { Siswa kelas XI } \\
\text { RPL SMK } \\
\text { Negeri } 2 \\
\text { Tabanan }\end{array}$ \\
\hline 3 & $\begin{array}{l}\text { Kevalidan } \\
\text { E-modul }\end{array}$ & Angket & $\begin{array}{l}\text { Ahli isi, ahli } \\
\text { desain, dan } \\
\text { Ahli Media } \\
\text { Pembelajaran }\end{array}$ \\
\hline 4 & $\begin{array}{l}\text { Respon } \\
\text { e-modul }\end{array}$ & Angket & $\begin{array}{l}\text { Siswa kelas XI } \\
\text { RPL dan guru } \\
\text { mata pelajaran } \\
\text { Pemrograman } \\
\text { Berorientasi } \\
\text { Objek SMK } \\
\text { Negeri } 2 \\
\text { Tabanan }\end{array}$ \\
\hline
\end{tabular}

Pada kegiatan observasi guna mendapat informasi sumber belajar dan karakteristik 
pembelajar, digunakan jenis angket terbuka. Melalui metode angket ini peneliti mengetahui masalah yang terjadi ketika pembelajaran berlangsung terkait sumber belajar, materi, media, dan ketertarikan siswa dalam pembelajaran Pemrograman Berorientasi Objek. Uraian singkat tentang teknis analisis data yang digunakan dalam penelitian ini adalah sebagai berikut.

\section{A. Validasi Data E-Modul}

Rumus yang digunakan menghitung persentase masing-masing subyek menurut Tegeh \& Kirna (2010:101) sebagai berikut.

Persentase $=\sum \frac{\text { jawaban } \mathrm{x} \text { bobot }}{\mathrm{n} \times \mathrm{b} \text { bobot }} \times 100 \%$

Keterangan : $\Sigma \quad=$ jumlah

$\mathrm{n}=$ jumlah seluruh item angket

Selanjutnya, untuk menghitung persentase keseluruhan subjek digunakan rumus :

$$
\text { Persentase }=\frac{F}{N}
$$

Keterangan :

$\mathrm{F}=$ jumlah persentase keseluruhan subjek $\mathrm{N}=$ banyak subjek

Untuk dapat mengetahui pencapaian pengembangan e-modul berdasarkan perhitungan persentase maka ditetapkan kriteria sesuai tabel tingkat pencapaian seperti terlihat pada Tabel 2 .

Tabel 2. Persentase tingkat Pencapaian

\begin{tabular}{|c|c|c|}
\hline $\begin{array}{l}\text { Tingkat } \\
\text { Pencapa } \\
\text { ian (\%) }\end{array}$ & $\begin{array}{l}\text { Kualifika } \\
\text { si }\end{array}$ & Keterangan \\
\hline $90-100$ & $\begin{array}{l}\text { Sangat } \\
\text { baik }\end{array}$ & $\begin{array}{l}\text { Tidak perlu } \\
\text { direvisi }\end{array}$ \\
\hline $75-89$ & Baik & Sedikit direvisi \\
\hline $65-74$ & Cukup & $\begin{array}{l}\text { Direvisi } \\
\text { secukupnya }\end{array}$ \\
\hline $55-64$ & Kurang & $\begin{array}{l}\text { Banyak hal yang } \\
\text { direvisi }\end{array}$ \\
\hline $0-54$ & $\begin{array}{l}\text { Sangat } \\
\text { kurang }\end{array}$ & $\begin{array}{l}\text { Diulangi } \\
\text { membuat produk }\end{array}$ \\
\hline
\end{tabular}

Sumber : (Tegeh \& Kirna, 2010)

\section{B. Analisi Data Respon Guru dan Siswa}

Untuk melakukan perhitungan analisis data respon siswa maka didasarkan pada rata-rata kelas $(\bar{x})$ dari respon siswa, Mi, SDi. Rata-rata kelas dari skor respon siswa dihitung menggunakan rumus (Nurkancana \& Sunartana, 1992).

$$
\bar{x}=\frac{\sum x}{N}
$$

Keterangan:

$$
\begin{aligned}
\bar{x}= & \text { Rata }- \text { rata kelas untuk skor } \\
& \text { respon siswa } \\
\sum x= & \text { Jumlah skor respon siswa } \\
\mathrm{N}= & \text { Banyaknya siswa }
\end{aligned}
$$

Sedangkan untuk mencari mean ideal (Mi) dan standar deviasi ideal (SDi) digunakan rumus sebagai berikut:

$\mathrm{Mi}=\frac{1}{2}($ skor maksimal + skor terendah $)$

$\mathrm{SDi}=\frac{1}{2}($ skor tertinggi + skor terendah $)$

Rata-rata kelas $(\bar{x})$ dari skor respon kemudian dikategorikan dengan menggunakan pedoman pada Tabel 3 .

Tabel 3. Kriteria Penggolongan Respon

\begin{tabular}{cll}
\hline No. & Interval & Kategori \\
\hline 1 & $\mathrm{Mi}+1,5 \mathrm{SDi} \leq \bar{x}$ & Sangat \\
& $\mathrm{Mi}+0,5 \mathrm{SDi} \leq \bar{x}<$ & Positif \\
2 & $\mathrm{Mi}+1,5 \mathrm{Sdi}$ & Positif \\
3 & $\mathrm{Mi}-0,5 \mathrm{SDi} \leq \bar{x}<$ & Kurang \\
& $\mathrm{Mi}+0,5 \mathrm{Sdi}$ & Positif \\
4 & $\mathrm{Mi}-1,5 \mathrm{SDi} \leq \bar{x}<$ & Negatif \\
& $\mathrm{Mi}-1,5 \mathrm{Sdi}$ & Sangat \\
5 & $\bar{x}<\mathrm{Mi}-1,5 \mathrm{Sdi}$ & Negatif \\
\hline \multicolumn{2}{l}{ Sumber : (Nurkacana \& Sunartana, 1992) }
\end{tabular}

\section{HASIL DAN PEMBAHASAN}

A. Implementasi E-Modul

Pengembangan e-modul pemrograman berorientasi objek memiliki tujuan untuk 
membantu penambahan sumber belajar, media pembelajaran, dan diharapkan dapat meningkatkan pemahaman materi pelajaran pemrograman berorientasi objek selama proses belajar mengajar di kelas. Pada saat melakukan obsevasi awal di sekolah SMKN 2 Tabanan didapat bahwa guru sulit mencari materi yang sesuai dengan kemampuan siswa sehingga siswa sulit memahami materi yang telah diberikan. Oleh karena itu pencarian materi dilakukan dengan menggabungkan materi yang terdapat di beberapa buku dan internet, materi yang di peroleh dari internet sebagaian besar memiliki sumber yang kurang jelas dan materi yang didapat juga rancu, sehingga perlu dikembangkanya suatu tempat atau wadah yang bisa memfasilitasi siswa dalam pencarian materi yang sesuai dengan silabus yang ada dan sudah tersusun secara sistematis, selain itu pada saat proses belejar mengajar guru masih menggunakan metode ceramah dan penyampaian materi yang menggunakan power point sehingga membuat siswa kurang tertarik dalam mengikuti proses pembelajaran tersebut, oleh karena itu pengembangan e-modul pada mata pelajaran pemrograman berorientasi objek di kelas XI RPL SMKN 2 Tabanan sangat diperlukan guna untuk meningkatkan kualitas pembelajaran yang dapat meningkatkan pemahaman siswa.

Pengembangan e-modul pemrograman berorientasi objek menggunakan model project based learning (PjBL), dengan tujuan membuat siswa menjadi terdorong lebih aktif dalam proses pembelajaran. Sesuai dengan tahapan pada model pengembangan ADDIE, tahapan pertama yang dilakukan adalah analyze (analisis) meliputi kegiatan analisis mata pelajaran yang terdiri dari: a) Analisis Tujuan dan Karakteristik Isi Bidang Studi, b) Menetapkan Indikator dan Isi Pembelajaran, c) Menetapkan Strategi Pengorganisasian Isi Pembelajaran, d) Menetapkan Strategi Penyampaian Isi Pembelajaran, e) Menetapkan Strategi Pengelolaan Pembelajaran. Selanjutnya melakukan analisis ketersediaan sumber belajar, dan analisis karakteristik pembelajar. Tahap kedua adalah design (desain) meliputi penyusunan draft modul dan perancangan e-modul. Tahap ketiga adalah development (pengembangan) yang meliputi kegiatan pengembangan modul, pengembangan e-modul, dan integrasi fitur Moodle pada e-modul. Kegiatan penyusunan modul meliputi pengumpulan bahan/materi pelajaran, pengetikan bahan ajar, dan penyusunan materi sesuai kompetensi yang diharapkan. Kegiatan pengembangan e-modul meliputi pembuatan media pembelajaran berupa tutorial dan simulasi, pengembangan rancangan antarmuka pada aplikasi Moodle berdasarkan rancangan struktur menu (sitemap), dan mengatur hak akses pengguna. Sedangkan kegiatan pengembangan integrasi fitur Moodle pada e-modul meliputi penerapan hasil modul ke dalam aplikasi Moodle hingga menjadi produk akhir berupa e-modul.

Pengembangan pada fitur Moodle disesuaikan dengan kerangka modul yang digunakan dan berisikan implementasi tahapan project based learning pada emodul. Tahap keempat adalah implementation (implementasi) yang dilakukan dengan menguji coba e-modul sesuai dengan peran dan fungsinya dalam proses pembelajaran untuk mengetahui sejauh mana manfaat produk yang dikembangkan. Tahapan uji coba dimulai dari review para ahli, kemudian dilanjutkan dengan uji coba perorangan, kelompok kecil, dan uji lapangan. Uji ahli yang pertama dilakukan adalah uji ahli isi pembelajaran. Setelah selesai melakukan uji ahli isi, kemudian dilanjutkan dengan uji ahli desain dan ahli media pembelajaran

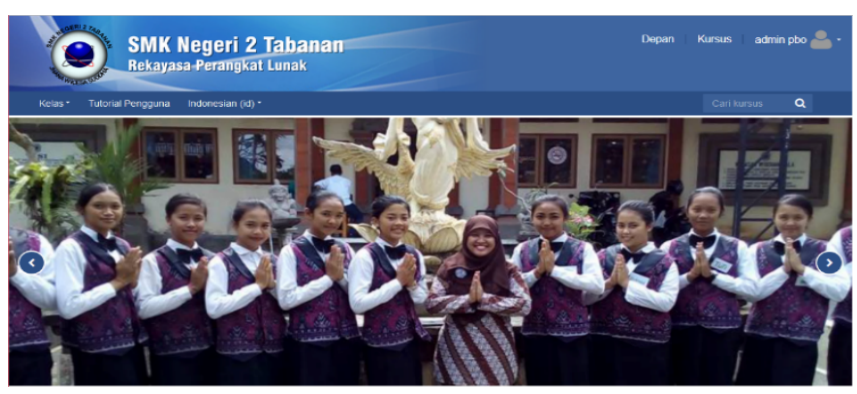

Gambar 4.1 Halaman Utama

B. Hasil Uji Ahli 
Hasil penilaian ahli isi berdasarkan angket menunjukkan bahwa tingkat pencapaian dari e-modul adalah "SESUAl" dan layak untuk dilanjutkan. Hal tersebut mengindikasikan bahwa materi pelajaran yang diimplementasikan dalam e-modul sudah relevan untuk digunakan dalam pembelajaran pemrograman berorientasi objek. Dalam uji ahli isi, ahli hanya memberikan komentar dan masukan yang sifatnya membangun, sehingga dalam uji ahli isi ini tidak terdapat revisi yang diberikan oleh ahli.

Hasil penilaian ahli desain pembelajaran terhadap produk pengembangan e-modul yang terdiri dari kelayakan isi, penyajian, tahap pembelajaran model project based learning, dan model pembelajaran sudah dinyatakan "SESUAI" dan layak untuk dilanjutkan. Melalui penerapan langkahlangkah model project based learning dalam pembelajaran membuat siswa lebih aktif melalui proyek yang diberikan pada masingmasing kegiatan belajar. Adapun masukan dan saran dari ahli desain yaitu menambahkan waktu deadline dalam pengerjaan per progres proyek tiap kegiatan pembelajaran

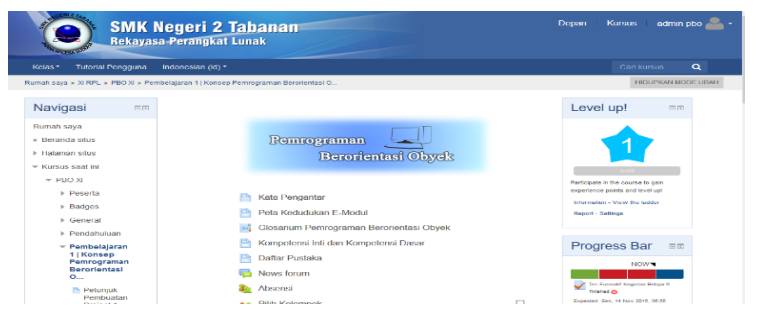

Gambar 4.2 Halaman Kegiatan Belajar

Hasil penilaian ahli media pembelajaran yang terdiri dari penggunaan bahasa dan keterbacaan, grafis, desain tampilan emodul, efektivitas, dan media yang dikembangkan dalam e-modul pemrograman berorientasi objek telah dinyatakan "SESUAl" layak untuk dilanjutkann. Hasil penilaian ahli media menandakan bahwa produk e-modul yang sudah dikembangkan layak untuk digunakan dalam pembelajaran pemrograman berorientasi objek. Adapun masukan dan saran dari ahli media, yang diberikan adalah seperti : Perbaiki manual penggunaan dan pembentukan kelompok

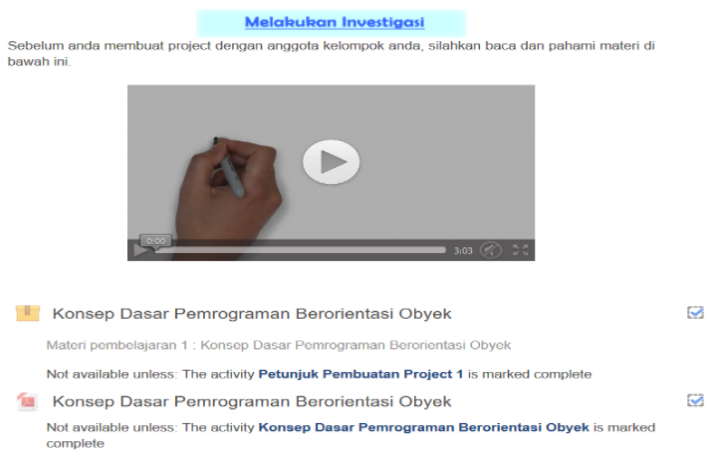

Gambar 4.3 Halaman Investigasi

C. Hasil Uji, Respon Siswa dan Guru

Kegiatan berikutnya yaitu melakukan implementasi yang meliputi uji perorangan, uji kelompok kecil, uji lapangan, uji respon guru, dan uji respon siswa. Subjek uji perorangan adalah tiga orang siswa kelas $\mathrm{XI}$ RPL di SMKN 2 Tabanan. Pemilihan ketiga subjek yang menjadi responden ini didasarkan pada prestasi mereka yaitu 1 prestasi tinggi, 1 dengan prestasi sedang, dan 1 dengan prestasi rendah, namun dari ketiga responden ini mereka sudah mampu mengoperasikan e-modul dengan baik setelah penulis menjelaskan mengenai emodul yang sudah dikembangkan. Dari hasil angket uji coba yang sudah diisi oleh masing-masing siswa, terdapat dua orang siswa memberikan tanggapan sangat baik $(66,67 \%)$, satu orang siswa yang memberikan tanggapan baik $(33,33 \%)$, dan tidak ada siswa yang memberikan tanggapan cukup, kurang, maupun sangat kurang.

Tabel 4 Penilaian Uji Perorangan

\begin{tabular}{lll}
\hline $\begin{array}{l}\text { Konversi } \\
\text { tingkat } \\
\text { pencapaian }\end{array}$ & $\begin{array}{l}\text { Persentase } \\
\text { (\%) }\end{array}$ & $\begin{array}{l}\text { Jumlah } \\
\text { Respon } \\
\text { den } \\
\text { (orang) }\end{array}$ \\
\hline Sangat Baik & $66,67 \%$ & 2 \\
Baik & $33,33 \%$ & 1 \\
Cukup & $0 \%$ & 0 \\
Kurang & $0 \%$ & 0 \\
Sangat Kurang & $0 \%$ & 0 \\
\hline
\end{tabular}


Grafik hasil rekapitulasi uji coba perorangan dapat dilihat pada gambar dibawah ini.

\section{Uji Coba Perorangan}

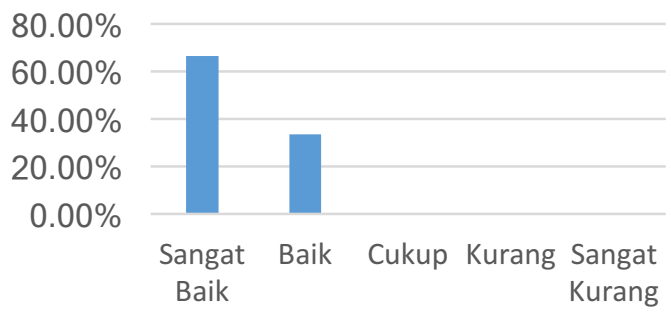

Gambar 6 Grafik Hasil Uji Perorangan

Persentase tingkat pencapaian e-modul yang dikembangkan dapat dihitung dengan rumus sebagai berikut.

$$
\begin{aligned}
& \text { Persentase }=\frac{\mathrm{F}}{\mathrm{N}} \\
& \text { Persentase }=\frac{268 \%}{3} \\
& \text { Persentase }=89,33 \%
\end{aligned}
$$

Sehingga rata-rata penilaian siswa adalah $89,33 \%$. Jika dikonversikan ke dalam tabel konversi termasuk dalam kategori baik dan tidak perlu revisi.

Setelah uji perorangan selesai, maka dilanjutkan dengan uji kelompok kecil. Uji kelompok kecil dilakukan oleh dua belas orang siswa kelas XI RPL. Dari hasil angket uji coba kelompok kecil yang diisi oleh masing-masing siswa, terdapat delapan orang siswa memberikan tanggapan sangat baik $(66,67)$, empat orang siswa memberikan tanggapan baik $(33,33 \%)$, dan tidak ada siswa yang memberikan tanggapan cukup, kurang, maupun sangat kurang.

Tabel 5 Penilaian Uji Kelompok Kecil

\begin{tabular}{|l|l|l|}
\hline $\begin{array}{l}\text { Konversi } \\
\text { tingkat } \\
\text { pencapaian }\end{array}$ & $\begin{array}{l}\text { Persentase } \\
(\%)\end{array}$ & $\begin{array}{l}\text { Jumlah } \\
\text { Responden } \\
\text { (orang) }\end{array}$ \\
\hline Sangat Baik & $66,67 \%$ & 8 \\
\hline Baik & $33,33 \%$ & 4 \\
\hline
\end{tabular}

\begin{tabular}{|l|l|l|}
\hline Cukup & $0 \%$ & 0 \\
\hline Kurang & $0 \%$ & 0 \\
\hline Sangat Kurang & $0 \%$ & 0 \\
\hline
\end{tabular}

Grafik hasil rekapitulasi uji kelompok kecil dapat dilihat pada gambar dibawah ini.

\section{Uji Kelompok Kecil}

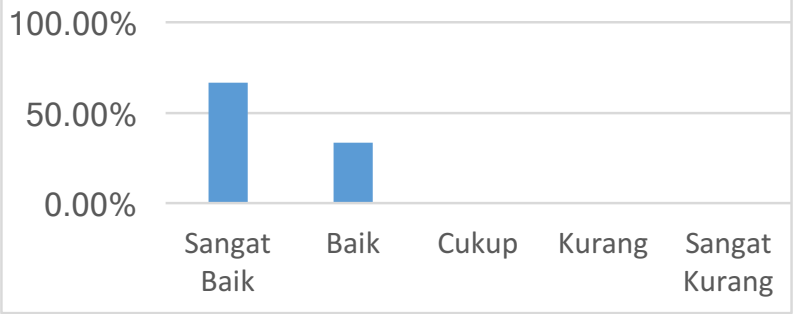

Gambar 7 Grafik Hasil Uji Kelompok Kecil

Persentase tingkat pencapaian e-modul yang dikembangkan dapat dihitung dengan rumus sebagai berikut.

$$
\begin{aligned}
& \text { Persentase }=\frac{\mathrm{F}}{\mathrm{N}} \\
& \text { Persentase }=\frac{1068 \%}{12} \\
& \text { Persentase }=89 \%
\end{aligned}
$$

Rata-rata penilaian dua belas orang siswa adalah (89\%). Jika dikonversikan ke dalam tabel konversi termasuk dalam kategori baik dan tidak perlu ada revisi. Adapun masukan terhadap e-modul melalui angket dikatakan e-modul pemrograman berorientasi objek sangat membantu dalam proses pembelajaran, serta memudahkan siswa memahami materi lebih cepat.

Setelah uji coba kelompok kecil selesai dilanjutkan dengan uji lapangan yang dilakukan oleh enam belas orang siswa kelas XI RPL di SMK Negeri 2 Tabanan. Dari hasil angket uji coba diperoleh 5 orang siswa memberikan tanggapan sangat baik $(31,25 \%), \quad 11$ orang siswa memberikan tanggapan baik $(68,75 \%)$, dan tidak ada siswa yang memberikan tanggapan cukup, kurang, maupun sangat kurang.

Tabel 6 Penilaian Uji Lapangan 


\begin{tabular}{lll}
\hline $\begin{array}{l}\text { Konversi } \\
\text { tingkat } \\
\text { pencapaian }\end{array}$ & $\begin{array}{l}\text { Persentase } \\
\text { (\%) }\end{array}$ & $\begin{array}{l}\text { Jumlah } \\
\text { Responden } \\
\text { (orang) }\end{array}$ \\
\hline Sangat Baik & $31,25 \%$ & 5 \\
Baik & 68,75 & 11 \\
Cukup & $0 \%$ & 0 \\
Kurang & $0 \%$ & 0 \\
Sangat & $0 \%$ & 0 \\
Kurang & & \\
\hline
\end{tabular}

Grafik hasil rekapitulasi uji lapangan dapat dilihat pada gambar dibawah ini.

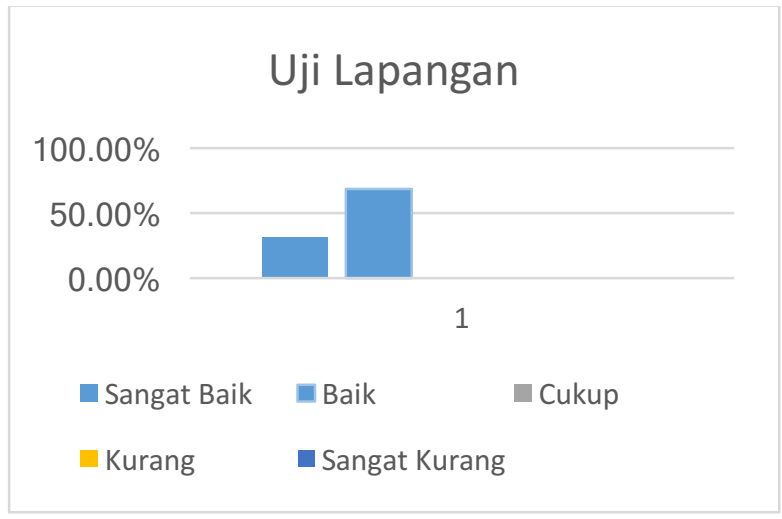

Gambar 8 Grafik Hasil Uji Lapangan

Persentase tingkat pencapaian e-modul yang dikembangkan dapat dihitung dengan rumus sebagai berikut.

$$
\begin{aligned}
& \text { Persentase }=\frac{F}{N} \\
& \text { Persentase }=\frac{1377 \%}{16} \\
& \text { Persentase }=86,06 \%
\end{aligned}
$$

Rata-rata penilaian keseluruhan responden uji lapangan adalah (86,06\%). Jika dikonversikan ke dalam tabel konversi tingkat pencapaian termasuk dalam kategori baik dan tidak perlu revisi pada e-modul. Berdasarkan temuan di lapangan, penggunaan e-modul dalam proses kegiatan belajar mengajar di kelas dapat membantu siswa memahami materi lebih cepat dan meningkatkan interaksi antar guru dan siswa. Melalui isi materi yang disajikan dalam bentuk teks, gambar, dan video dalam e-modul siswa lebih mudah memahami materi dan sangat membantu dalam pengerjaan proyek. Keberhasilan model pembelajaran project based learning untuk meningkatkan aktivitas belajar siswa disebabkan oleh penerapan model project based learning yang membantu siswa terlibat secara aktif mengikuti pembelajaran. Model project based learning memberikan kesempatan siswa untuk belajar menyenangkan, sehingga menumbuhkan minat siswa untuk belajar dan mendorong siswa untuk mengembangkan keterampilannya.

Setelah hasil uji lapangan selesai dilakukan, selanjutnya dilakukan pengambilan respon guru terhadap pengembangan e-modul pada mata pelajaran permograman berorientasi objek. Uji respon guru dilakukan oleh satu orang responden yaitu Ni Ketut Eniyawati,S.Kom dan memperoleh rata-rata sebesar 37 , jika dikonversikan ke dalam tabel kriteria penggolongan respon maka hasilnya termasuk dalam kategori positif. Proses uji selanjutnya dilakukan dengan pengambilan respon siswa. Subjek uji coba respon siswa adalah terdiri dari 16 orang siswa kelas $\mathrm{XI}$ RPL yang telah belajar menggunakan emodul. Hasil angket respon siswa terhadap pengembangan e-modul pemrograman berorientasi objek memperoleh rata-rata sebesar 63,93, jika dikonversikan ke dalam tabel kriteria penggolongan respon maka hasilnya termasuk dalam kategori positif. Berdasarkan hasil respon guru dan siswa dapat dikategorikan membantu siswa dalam memahami mata pelajaran pemrograman berorientasi objek dan berhasil mengatasi permasalahan tidak adanya modul ajar.

Hasil penelitian e-modul berbasis model pembelajaran project based learning pada mata pelajaran pemrograman berorientasi objek ini, sejalan dengan penelitian Sitti Ghaliyah, Fauzi Bakri dan Siswoyo (2015) tentang Pengembangan modul elektronik berbasis model Learning Cycle 7E pada pokok bahasan Fluida dinamik untuk siswa SMA kelas XI. yaitu sama-sama memeproleh penilaian baik oleh ahli materi, ahli media, ahli pembelajaran, dan guru, serta uji coba lapangan. Dalam 
implementasi emodulnya, terdapat tes formatif yang berguna untuk mengetahui sejauh mana pemahaman yang siswa dapatkan tentang materi yang diberikan, serta menguji kemampuan siswa terhadap materi tersebut. Penelitian terkait lainya yang dilakukan oleh Heru Edi Kurniawan (2013), yaitu sama - sama memperoleh kualitas produk modul pembelajaran yang dikembangkan melalui serangkaian uji validitas oleh validator mendapatkan nilai dengan kategori baik sehingga modul pembelajaran yang dikembangkan layak digunakan. Penelitian terkait lainya oleh Putra, Wirawan, dan Sindu (2017) tentang Pengembangan E-Modul Berbasis Project Based Learning Pada Mata Pelajaran Administrasi Basis Data Kelas XII Rekayasa Perangkat Lunak Di SMK Negeri 2 Tabanan yaitu sama - sama memperoleh rata - rata hasil respon positif dari siswa dan guru, dimana respon siswa mendapat rata - rata 63,93 jika dikonversikan ke dalam tabel konversi tingkat pencapaian termasuk kategori positif, sedangkan respon guru mendapatkan rata - rata 37 yang jika dikonversikan ke dalam tabel konversi tingkat pencapaian termasuk kategori positif, serta mendapat komentar yang positif. Prasetya, Wirawan, dan Sindu (2017) tentang Pengembangan E-Modul Pada Mata Pelajaran Pemodelan Perangkat Lunak Kelas XI Dengan Model Problem Based Learning Di SMK Negeri 2 Tabanan yaitu sama - sama mendapatkan hasil rata - rata pengujian serta respon siswa dan guru yang positif sehingga pengembangan E-Modul dinyatakan baik dan layak untuk diterapkan dalam proses pembelajaran.

Berdasarkan pembahasan di atas, penilaian-penilaian yang dilakukan oleh ahli isi, ahli desain pembelajaran, ahli media, uji coba perorangan, uji coba kelompok kecil, uji lapangan, maupun hasil respon guru dan siswa termasuk dalam kategori baik dan mendapat respon positif. Berdasarkan penilaian tersebut, secara garis besar pengembangan e-modul berbasis model project based learning pada mata pelajaran pemrograman berorientasi objek telah menunjukkan adanya keberhasilan dan layak digunakan sebagai sumber belajar untuk siswa kelas XI RPL di SMK Negeri 2 Tabanan. Hal ini didukung pula dengan beberapa pernyataan siswa yaitu dengan adanya e-modul pemrograman berorientasi objek sangat membantu dalam proses pembelajaran, maupun memudahkan siswa memahami materi lebih cepat. Melalui penerapan e-modul pemrograman berorientasi objek ini diharapkan dapat membantu guru selama proses pembelajaran dan masalah selama proses pembelajaran terkait sumber belajar mampu teratasi, intensitas belajar siswa meningkat, dan membantu siswa menjadi lebih aktif dalam proses pembelajar.

\section{SIMPULAN DAN SARAN}

Berdasarkan hasil penelitian dan pembahasan pada penelitian pengembangan e-modul berbasis model pembelajaran project based learning, maka penulis dapat menarik kesimpulan sebagai berikut. (1) Hasil rancangan dan implementasi pengembangan e-modul berbasis project based learning pada mata pelajaran pemrograman berorientasi objek kelas XI RPL SMK N 2 Tabanan sudah dinyatakan berhasil dikembangkan. Hal ini dapat dilihat dari rata-rata persentase berdasarkan hasil pengujian yang telah dilakukan. (2) Respon guru terhadap pengembangan e-modul berbasis project based learning pada mata pelajaran pemrograman berorientasi objek kelas XI RPL SMK N 2 Tabanan didapatkan rata-rata sebesar 37. Jika dikonversikan ke dalam tabel kriteria penggolongan respon maka hasilnya termasuk dalam kategori positif. Sedangkan untuk respon siswa terhadap pengembangan e-modul ini memperoleh rata-rata sebesar 63,93. Jika dikonversikan ke dalam tabel kriteria penggolongan respon maka hasilnya termasuk dalam kategori positif.

Berdasarkan pengamatan penulis, terdapat beberapa hal yang dapat dijadikan bahan pertimbangan untuk ditindak lanjuti. (1) Pengembangan e-modul pada mata pelajaran pemrograman berorientasi objek ini hanya sampai pada kegiatan belajar pada semester ganjil, jadi diharapkan untuk 
peneliti selanjutnya agar dapat mengembangkannya menjadi 1 tahun pelajaran. (2) Produk e-modul berbasis project based learning pada mata pelajaran pemrograman berorientasi objek kelas XI RPL SMK N 2 Tabanan yang dikembangkan belum sampai pada tahap pengukuran hasil belajar siswa. Oleh karena itu, perlu diadakan pengkajian lebih lanjut mengenai efektivitas penggunaan e-modul berkaitan dengan pengukuran hasil belajar siswa menggunakan e-modul ini melalui penelitian eksperimen.

\section{DAFTAR PUSTAKA}

Anglada, D. (2007). An Introduction to Instructional Design: Ultilizing a Basic Design Model. Retrieved from http://www.pace.edu/ctlt/newsletter

Baharuddin. (2010). Pendidikan \& Psikologi Perkembangan. Jogjakarta: ar-ruzz media.

Kusuma, S Y. (2005). Desain Pengembangan Bahan Ajar Matematika Interaktif Berbasiskan Teknologi Komputer. Bandung, 23.

McGriff, J. S. (2000). Intructional System Design(ISD): Using the ADDIE Model. Journal of Collage of education (2000). Penn: Penn State University, 1.

Mulyasa, E. (2005). Kurikulum Berbasis Kompetensi: Konsep Karakteristik, Implementsi, dan Inovasi. Bandung: Remaja Rosdakarya.

Musfiqon. (2012). Metodologi Penelitian Pengembangan. Jember:

Penasalsabila, 190.

Nurkancana, S. \&. (1992). Evolusi Hasil Belajar. Surabaya: Usaha Nasional.

Prasetya, I G. A. S., Wirawan, I M. A., \& Sindu, I G. P. (2017). Pengembangan E-Modul Pada Mata Pelajaran Pemodelan Perangkat Lunak Kelas XI Dengan Model
Problem Based Learning Di SMK Negeri 2 Tabanan. Jurnal Pendidikan Teknologi dan Kejuruan, 14(1).

Prasetyo, Z. K. (2011). Pengembangan Perangkat Pembelajaran Sains Terpadu Untuk Meningkatkan Kognitif, Keterampilan Proses, Kreativitas serta Menerapkan Konsep IImiah Peserta Didik SMP. Program Pascasarjana UNY.

Putra, P. P., Wirawan, I M. A., \& Sindu, I G. P. (2017). Pengembangan E-modul berbasis Project Based Learning pada Mata Pelajaran Administrasi Basis Data Kelas XII Rekayasa Perangkat Lunak di SMK Negeri 2 Tabanan. Jurnal Pendidikan Teknologi dan Kejuruan, 14(1).

Santyasa, I. W. (2009). Teori Pengembangan Modul. Bali: Universitas Pendidikan Ganesha.

Santyasa, I. W. (2011). Pembelajaran Inovatif. Singaraja: Undiksha.

Suartama, K. I. (2014). E-Learning Berbasis Moodle. 39-57: Garha IImu.

Suderadjad, H. (2005). Manajemen Peningkatan Mutu Berbasis Sekolah; Peningkatan Mutu Pendidikan Melalui Implementasi KBK. Bandung: Cipta Lekas Garafika, 17.

Sugiyono. (2009). Metode Penelitian Pendidikan Pendekatan Kuantitatif, Kualitatif dan $R$ \& D. Bandung: Alfabeta.

Tegeh, M. I. (2013). Pengembangan Bahan Ajar Metode Penelitian. 101.

Trianto. (2008). Mendesain Pembelajaran Kontekstual (Contextual Teaching And Learning). Jakarta: Cerdas Pustaka.

Wena, M. (2009). Strategi Pembelajaran Inovatif Kontemporer (Suatu Tinjauan Konseptual Operasional). Jakarta: Bumi Aksara. 
Wijayanto, M. S. (2014). Pengembangan EModul Berbasis Flip Book Maker dengan Model Project Based Learning unutuk Mengembangkan Kemampuan Pemecahan Masalah Matematika. Proseding Mathemaics and Sciences Forum, 1-4 